\title{
Culture Through Prism of Engaged Poetry
}

\author{
Tina Laco \\ University of Mostar, Mostar, Bosnia and Herzegovina
}

\begin{abstract}
The paper is actually a literary research on (re)constructing cultural image of post-yugoslavian society, formed through literary sources, i.e., poetry. Using examples of award-winning young authors-Bojan Krivokapic, Mirko Bozic, and Sima Majic, different types of so-called engaged poetry are indicated. This kind of poetry is used to subtly, critically, or in a very subversive way relate to the existing world, but also a new postmodern identity is formed through specific and carefully chosen poetic lexis, deprived of any kind of structure or limitation. The poetry of mentioned authors is used as a provisory example in order to indicate that post-war period (as well as postmodern time) changes the perception of identity, from nationally and politically oriented structure to individual and subversive, conventions-free comprehension of Oneself. Although the three authors are very different in style and expression, what brings them together is tendency to escape conventional and traditional cultural images in order to emphasize the importance of Being Different, but Equally Rightful.
\end{abstract}

Keywords: culture, engaged poetry, language, postmodernism, identity

\section{Introduction}

Provisory examples taken for this research are just a representative part of a certain literary tendency in post-yugoslavian countries. This tendency is recognized as changing the former comprehension of the phrase "engaged poetry", i.e., making that phrase more suitable for young, post-war generation of poets, who are becoming less interested in war as two-sided, nationally oriented mess and more interested in comprehension of identity as more complex cultural product. The purpose of this study is to examine how young, contemporary poets in post-yugoslavian society perceive their identity and their culture and in which way their perception of identity and culture expressed through poetry changes comprehension of "engaged poetry" (which is usually considered to be very nationally and politically related).

Engaged poetry has spontaneously changed its basic meaning in this geographical sphere since the phrase has intensively entered the critics during politically most sensitive years of former Yugoslavian countries. For example, Croatian literature is well-known to have had specific poetic genre called "budnice" and "davorije" during the process of Hrvatski Narodni Preporod (Croatian National Revival), purpose of which was to "awake" the nation, to lift the national awareness in battle for freedom and independence (for further reference, see Šicel, 2004). During the communistic regime, there were many authors who were considered to be "engaged writers" for sending indirect national messages and expressing criticism through their literary works, often using metaphors and allegories to protect themselves from the punishment of the regime.

In the last decade, specifically last couple of years, more than 20 years after the war on former Yugoslavian space is over, new generation of poets emerged indicating common tendency to question identity

Tina Laco, professor, Ph.D. candidate, Faculty of Philosophy, University of Mostar. 
on another level; their perception of identity is based on individuality rather than on nationality or common (national, political) culture. Their engagement is not expressed through any kind of call for liberation or support of any national, cultural (iconic, symbolic, typical, conventional, or traditional) construct - they are in quest of identity and aim to liberate identity from any kind of limitations (gender, sexual, national, cultural, social, and political). Their poetic voice tends to be universal and engaged in terms of promoting individuality.

Critical reviews regarding this poetry usually neglect this engaged identitary reflection and tend to refer to it as poetry "on the verge of engaged". Concerning the fact that postmodernism destabilizes the term "engaged", the mentioned new generation of poets is actually not "on the verge" - these poets can be rightfully called, according to Croatian phrase "borac perom"-pen fighters. Poetry of Bojan Krivokapic, Mirko Bozic, and Sima Majic, young but already award-winning poets, proves that reconstruction and destabilization of a certain cultural image is an engaged act by itself, especially because it shifts the meaning from "local" to "universal". Furthermore, these authors are interesting because they have completely different ways of processing society given cultural constructs and accepting it only to fight back with (more or less) subtly dosed irony, building their own cultural architectonics, tending to be universally meaningful, and being aware that accepting postmodernism also means redefining limited (social and cultural) constructs and revalorization identity essence.

\section{Bojan Krivokapić, “Žoharov let” (Bojan Krivokapic, Cockroach’s Flight')}

Bojan Krivokapic became known to wider circle of audience after winning an award for his short story collection Trci Lilit zapinju demoni (Run Lillit the Demons are Stumbling, 2013). His short stories are unusual, innovative but also slightly shocking because of the fact that he wrote them in three languages deriving from three nations who were fighting against each other in the war of 1991 in Croatia, Serbia, and Bosnia and Herzegovina. Krivokapic, of course, uses three mutually almost identical languages, to indicate absurdity of dividing and judging people based on their nation, religion, or language. His perception of "national" and "cultural identity" as two synonymous absurdities is present in his poems, through which he uses strong irony and sarcasm to emphasize his attitude towards traditional cultural markers. Krivokapic's specific literary engagement is very radically directed against collective habitus. His subversion of conventional comprehension of cultural identity is revealed through his choice of topics, poetic images which would be more typical and suitable for "stvarnosna poezija" (reality poetry), ${ }^{2}$ lyrical visualization which captures his personal cry, and finally through his engagement stressed with lines such as:

Politika identiteta
Fragilnost subjekta
Performativnost roda
Misli se smenjuju
Sto lice na teme
I na pitanja
Tome nas nisu ucili
("Nedeljom ujutru, kad...")

\author{
Politics of identity \\ Fragility of subject \\ Performativity of gender \\ Thoughts are shifting \\ They look like themes \\ And questions \\ We were not taught to it \\ (“Sunday Morning, when...”)
}

\footnotetext{
${ }^{1}$ Concerning that the author of this paper has been using literature translated in Croatian, titles of poetry books and poems, as well as poetic texts, are just the author's suggestion of possible translation in English for better comprehension and are marked with italics throughout the text.

2 "Stvarnosna poezija" (the closest translation in English would be "reality poetry") is a term which marks literary tendency that Croatian critics recognized during the 90's; the term became theoretically more important and legitimate with works of Robert Perisic and Damir Sodan.
} 
Following ideas of Pierre Bourdieu's sense of individual and collective, expressed through habitus, or as Krivokapic understands it, collective habitus, the author finds contemplation and action on national and individual-limiting level unacceptable because it indicates inert and lethargic perception of tradition and dogmatic acceptance of conventions. Acting by traditional default and inheriting historical impositions without any critical observation towards it is a certain way to self-destruction in social sense. Dispersion of collective, but also individual identity becomes creative line for Krivokapic who, by following ideas of Albert Camus (2011), tends to escape from the "great literature"-because it is directed to creating closed worlds or completed types ${ }^{3}$ - and to use "small stories" in order to open vast individual space, far away from collective structure and ideology (which is, partially, one of the main postmodern tendencies as well, with reference to Lyotard's Postmodern Condition).

Krivokapic's poetic linguistic patterns, full of carefully balanced sarcasm scattered over seemingly simple and everyday images ironically invoke traditional internal cultural matrix, based on a structure that the author would refer to as absurd default. Neglecting and strongly opposing to this kind of construct, the author creates engaged complex background of transition world, post-yugoslavian world, world of media, consumer society, etc., without any existential pathos or apocalyptic prophecy involved.

This voluntary exile from any kind of imposed structure is not an eccentric act, but rather an absolutely planned malversation of linguistic patterns. This brings out the author's general idea that recognizing certain linguistic units as specificities of certain linguistic domains is conditioned only by imposed mental boundaries.

\section{Mirko Bozic, “Mrlje na njenim rukama” (Mirko Bozic, Stains on Her Hands)}

Manipulation of poetic language through brilliant and lucid metaphors, with tendency to be subversive and to create new system of identitary legitimation, is also to be seen in poetry of Mirko Bozic.

Ja ne znam pisati pjesme
O stoljetnim uljudbama, predzidima i steccima
Ne znam vam ja pjevati
Ni o mucenicima, jamama i smokvama
A o zastavama, narodima i sipcima
Bolje da vam ni ne govorim

(“Domoljub”)

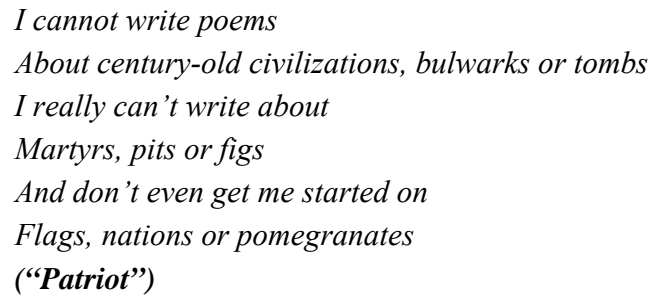

It is obvious that Bozic uses more specific and very clear cultural marks and iconic national symbols in order to play with language to the level of ridiculousness, but his verses can be semiotically translated into serious critical contemplations (especially in poems such as "Domoljub"/"Patriot" or "Balada o četkici za zube"/"Ballad of the Toothbrush"). These contemplations are constantly questioning possibilities, needs, and sense of having one firm and coherent cultural pattern. Aiming to solve these doubts, Bozic presents paradox as only possible result of cultural limitations, as well as limitations in general, and also nullifies the possibility of firm identity. While Krivokapic uses his linguistic structure to bring out questions of culture and identity into the spheres of philosophy and existentialism, Bozic is trying to "loose" and trivialize linguistic instruments aiming to resignate from questioning identity inside of limited and culturally imposed circle — in fact, he refuses

\footnotetext{
3 "Napor velike literature čini se da je usmjeren k stvaranju zatvorenih svjetova ili dovršenih tipova" (The effort of great literature seems to be directed towards creating closed world or completed types, translated by the author, according to Camus, 2011)
} 
to be inside the sphere of given/imposed cultural markers. His poetic style is appealing precisely because of the perfect congruency of linguistic statement and critical load of its content. In other words, as much as he perceives culture as trivial and stereotypical, at the same time he trivializes and stereotypes the language.

It is interesting that the poems deliberately deprived of subtlety, seeming to be politically radical in expression, show less tendency of engagement than those using different levels of metaphors and carrying allegorical meaning:

neka bog cuva europsku uniju
visoke predstavnike ministre i predsjednike komisija
bruxelles volim tvoje granitne birokratske monstrume
uredske mrave koji se brinu da nasa majcica europa
savrseno funkcionira i ciste njezino debelo crijevo
od ilegalnih imigranata iz treceg svijeta
i ostalih bakterijskih nametnika gljivica i polipa

neka bog cuva europsku uniju visoke predstavnike ministre i predsjednike komisija bruxelles volim tvoje granitne birokratske monstrume uredske mrave koji se brinu da nasa majcica europa od ilegalnih imigranata iz treceg svijeta i ostalih bakterijskih nametnika gljivica i polipa

\author{
god save the European Union \\ high representatives ministers and commission presidents \\ Bruxelles I just love your granitic bureaucratic monstrums \\ office ants making sure that our mother Europe \\ functions perfectly and cleaning its colon \\ from illegal immigrants of the third world \\ and other bacterial parasites fungi and polyp
}

Bozic's poetry reflects the new meaning of poetic engagement in most radical way: Even being aware of the fact that questions of national rights and equality between three nations living in one state are the main obsession in local and political sense, he refuses to accept these kinds of determinations as top priority. His universal mission, so to speak, seems to be focused on wrongful and vast differences between "the Leaders" (the rich ones, politically important people) and "the Power deprived" (middle-class people). Constructing his poems as ironical social declamations, it seems that the most important message is hidden between verses, with what is not said.

However, radically insisting on ironic audacity of his textual poetic proclamations (his poems are often to be read as extended aphorisms), his poetry tends to lack rhythm and poetic resonance.

Critical declamations in works of both authors are transparently expressed through verses such as:

$\begin{array}{ll}\text { Ja imam privilegiju } & \text { I have the privilege to be } \\ \text { Da budem u domu onih } & \text { In the home of those } \\ \text { Koje biram } & \text { I choose } \\ \text { Bez domovine ili ognjista } & \text { Without homeland or hearth }\end{array}$

(Krivokapicev "Zoharov let")

or

\author{
Homeland is an abstract term for me \\ I haven't been chased out of nowhere \\ I live where I was born, very boring \\ (Bozic's “Patriot”)
}

These verses are an act of voluntary and conscious exile which is considered to be immanent in places where "culture" is synonym for "identity", "nation", "civilization", "political choice", or as Bozic sarcastically notices, "tombs", "cross", or "pomegranate". Ergo these authors break their poetic discourse into potentially unstable forms, textual fluids, contemplatively complex prose poems, where every verse portrays one cultural (deconstructed) circle.

\section{Sima Majic, "Potkožni sjever” (Sima Majic, North Underskin)}

Sima Majic uses subtle subversiveness in the form of essayistic and hermetical poetic relations in order to 
create more than an "active reader": Her poetry requires very engaged recipient and eclectic co-author. Her constant games of poetic, versed, textual, semantic "load and relief" are reflected through new structural vista, where the escape of suggested shallowness of the outside world and crash of culture represent only possible opportunity of personal engagement. Majic's poetic exile reflects only ironical reviews, pretentious scorn, and cunning comments:

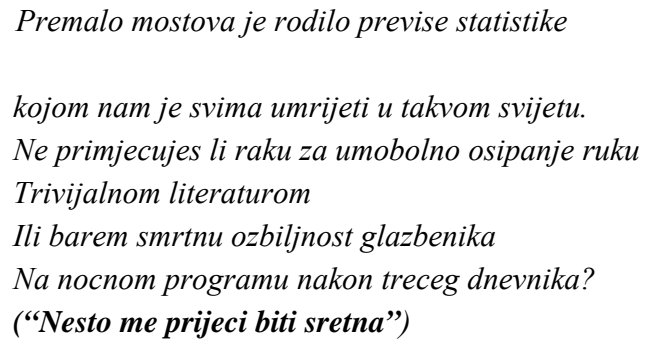

\author{
A small number of bridges gave birth to a large number of \\ statistics \\ And we are all about to die in this kind of world \\ Aren't you noticing this hole for mindblowing hand rash \\ Caused by trivial literature \\ Or at least mortal seriousness of a musician \\ During night programme after third edition of TV news
}

("Something keeps me away from being happy")

The author uses these unusual relations between linguistic and stylistic figures in order to create subtle defense mechanism, to shelter her identity from the culture she perceives as painfully trivial and unsensitive; it also reflects her tendency to find her own modus vivendi and to establish a dialogue with an arbitrary experience of what traditional/conventional really is. Mere poetic reflections are used to protest against living in civilization in which lyric subject obviously feels unstable, exiled and forced, even chased out, so the author sets yearning as focus of her poetry, creating so-called textual lacunas that open potentially vast spaces of imagination. Her escape from imprisonment inside of trivial postmodern society and degraded culture is being hyperbolated with linguistic statement inside of which lack of syntactic tension can be noticed in order to create mechanism of penetrating into newly designed world.

Majic's poetry strongly evokes the idea suggested in Baudelaire's "Windows" (n.d.): "Looking outside into an open window one never sees as much as when one looks through a closed window". Majic is an author who radically insists on vision in order to find, in Baudelaire's words, commodité. This young poet varies between keeping substantial definition of poetry (poetic language), on one hand, and reflecting it through a new structural vision. Unlike Krivokapic's and Bozic's poetry, Majic's poems are in strong dialogue with tradition, her poetic voice reflects somewhat of Romantic style, but she tends to trivialize and ironize traditional comprehension of subject and identity. She prefers process over state and perceives contradiction rather than harmony as natural condition, in fact, as the only possible way of individual development.

This author's subversion towards what she often refers to as stupidity of modern world exploits universal critical meaning even in verses which are seemingly intimate:

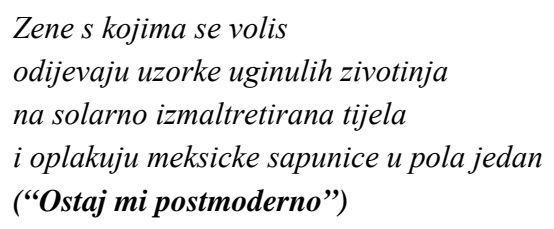

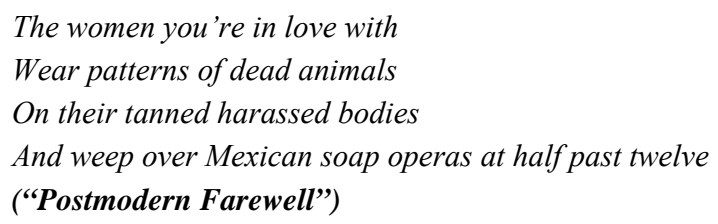

\section{Conclusion}

Examples of Bojan Krivokapic, Mirko Bozic, and Sima Majic, but also many other contemporary poets of Eastern and South-Eastern Europe prove that new generations try to radically follow typical Borges attitude: "Authors do not exist, only literature exists." This kind of relationship towards literature and art in general 
makes them very engaged supporters of postmodern comprehension of identity. Running away from imposed and determinate cultural practice, which is being perceived as very limited, extremely political and inhumane on their side, these authors use their linguistic, stylistic, and literary instruments to radicalize the form and create their own identity, which is proud to be within the category of "no one's belonging".

However, it is also important to emphasize that tendency to be universally (rather than nationally) important is mirrored in the fact that these authors perceive world as constant battlefield between One and The Other. Social provenance of their engagement is indisputable, but their poems tend to annulate national and political boundaries (which explains their contempt towards politically constructed symbols - flags, anthems, etc.) in order to articulate their main postulate contained in the idea that the voice of The Other should be heard. The Other is not necessarily a minority - the Other means the Opposite, but rightfully Equal.

The given examples of new generations' poetry show tendency to radically articulate identity of The Other who refuses to define itself based on already existing and standard markers because it feels that it would unrightfully limit their freedom and diminish their creative and performative space. Unlike earlier comprehension of engaged poetry, which was based on national unity deriving from very specific and sensitive political, social, and historical background of those times, (post)modern world uses literature, arts, in fact, any kind of creative and dynamic expression to prove that unity and harmony of the world can be accomplished simply by accepting differences between individuals and respecting their "otherness". Poems of Krivokapic, Bozic, and Majic in an essence aim to dissolve identity in order to construct one.

\section{References}

Baudelaire, C. (n.d.). Windows. Retrieved from http://www.poemhunter.com/poem/windows/

Božić, M. (2012). Mrlje na njenim rukama (Stains on her hands). Karlovac: Matica hrvatska.

Camus, A. (2011). Pobunjeni čovjek (The rebel). Zagreb: Matica hrvatska.

Krivokapic, B. (2014). Žoharov let—gemischt poezija (Cockroach's flight—Gemischt poetry). Stolac: Slovo Gorčina (in print).

Majić, Š. (2013). Potkožni sjever (North underskin). Karlovac: Matica hrvatska.

Said, E. (2002). Razmišljanja o egzilu. Retrieved from http://www.zarez.hr/clanciin/razmisljanja-o-egzilu. (Translated from Chapter Reflexions on exile, in the book Reflections on exile and other essays, by L. Kozole, Massachusetts: Harvard University Press)

Šicel, M. (2004). Povijest hrvatske književnosti XIX. stoljeća. Knjiga I. Od Andrije Kačića Miošića do Augusa Šenoe (1750-1881) (History of Croatian nineteenth century literature. Book 1. From Andrija Kacic Miosic to August Senoa). Zagreb: Naklada Ljevak.

Šodan, D. (2010). Drugom stranom. Antologija suvremene hrvatske „stvarnosne poezije“ (Through the other side. Anthology of contemporary Croatian "reality poetry”). Zagreb: Ljevak. 